\title{
Putting yourself in someone else's shoes: The impact of a location-based, collaborative role-playing game on behaviour
}

Citation for published version (APA):

Schmitz, B., Schuffelen, P., Kreijns, K., Klemke, R., \& Specht, M. (2015). Putting yourself in someone else's shoes: The impact of a location-based, collaborative role-playing game on behaviour. Computers \& Education, 85, 160-169. https://doi.org/10.1016/j.compedu.2015.02.012

DOI:

10.1016/j.compedu.2015.02.012

Document status and date:

Published: 01/07/2015

Document Version:

Other version

Please check the document version of this publication:

- A submitted manuscript is the version of the article upon submission and before peer-review. There can be important differences between the submitted version and the official published version of record. People interested in the research are advised to contact the author for the final version of the publication, or visit the DOI to the publisher's website.

- The final author version and the galley proof are versions of the publication after peer review.

- The final published version features the final layout of the paper including the volume, issue and page numbers.

Link to publication

\section{General rights}

Copyright and moral rights for the publications made accessible in the public portal are retained by the authors and/or other copyright owners and it is a condition of accessing publications that users recognise and abide by the legal requirements associated with these rights.

- Users may download and print one copy of any publication from the public portal for the purpose of private study or research.

- You may not further distribute the material or use it for any profit-making activity or commercial gain

- You may freely distribute the URL identifying the publication in the public portal.

If the publication is distributed under the terms of Article $25 \mathrm{fa}$ of the Dutch Copyright Act, indicated by the "Taverne" license above, please follow below link for the End User Agreement:

https://www.ou.nl/taverne-agreement

Take down policy

If you believe that this document breaches copyright please contact us at:

pure-support@ou.nl

providing details and we will investigate your claim.

Downloaded from https://research.ou.nl/ on date: 26 Apr. 2023 


\title{
Putting yourself in someone else's shoes: The impact of a location- based, collaborative role-playing game on behaviour
}

\author{
Birgit Schmitz $^{\text {a, *, }}$, Petra Schuffelen ${ }^{\text {b }}$, Karel Kreijns ${ }^{\text {a, } 1}$, Roland Klemke ${ }^{\text {a, }}$, \\ Marcus Specht ${ }^{\mathrm{a}, 1}$ \\ a Welten Institute, Research Centre for Learning, Teaching and Technology, Faculty of Psychology and Educational Sciences, Open University of the \\ Netherlands, Valkenburgerweg 177, 6419 AT Heerlen, Netherlands \\ ${ }^{\mathrm{b}}$ Caphri, School for Public Health and Primary Care, Maastricht University, Universiteitssingel 40, 6229ER Maastricht, Netherlands
}

\section{A R T I C L E I N F O}

\section{Article history:}

Received 5 September 2014

Accepted 12 February 2015

Available online 5 March 2015

\section{Keywords:}

Mobile games

Mobile learning

Serious games for health

Health behaviour change

\begin{abstract}
A B S T R A C T
The goal of this study was to probe the effectiveness of a mobile game-based learning approach in modifying behavioural outcomes and competence. The experiment was set against the background of low rates of laymen providing CPR during sudden cardiac arrests. A post-test control group design was used to contrast and evaluate the effects of the two different types of learning. Two hundred two students were randomly assigned to two conditions, a game-based variant simulating an emergency situation (experimental group), and an instruction-based approach (control group). After the intervention participants completed a questionnaire assessing self-prediction, self-efficacy, attitude, subjective norm, empathy and competence. The largest arguably significant difference between the two groups showed in self-prediction and capacity beliefs. Results further revealed a positive relationship between selfprediction and the variables attitude and self-efficacy. The type of scenario did not translate into the other concepts we assessed, though, and results were inconclusive regarding the effectiveness of the type of learning scenario and CPR knowledge. We explain the small effect size partly by the experimental procedure and the design of the game intervention, which is discussed in the course of this article.
\end{abstract}

(c) 2015 Elsevier Ltd. All rights reserved.

\section{Introduction}

In Europe, approximately 350,000 people die each year due to out-of-hospital cardiac arrest (OOH-CA). On a daily basis, this is around the equivalent of two full jumbo jets, which puts this cause of death in third place behind all cancers combined and other cardiovascular causes (ESA, 2014). Around 100,000 of these deaths could be prevented if members of the public, beginning with schoolchildren, had the resuscitation knowledge needed to save a life. Despite an extensive introduction of cardiopulmonary resuscitation (CPR) training measures in the 1960s, the rate of laymen providing CPR during cardiac arrests is still low (Plant \& Taylor, 2013; Vaillancourt, Wells, \& Stiell, 2008). It seems that knowledge on how to provide CPR is not the only decisive factor. Studies investigating the impact of psychosocial factors on laymen providing CPR identified factors such as perceived risk of infection with a communicable disease during CPR, or disagreeable physical characteristics, e.g. the presence of blood, which influenced and even prevented lay helpers' willingness to provide CPR (Cho, Sohn, Kang, Lee, Lim, Kim et al. 2010; Coons \& Guy, 2009; Johnston, Clark, Dingle, \& FitzGerald, 2003; Kanstad, Nilsen, \& Fredriksen, 2011; Query, 2006).

Coons and Guy (2009) concluded, "the relative importance of the reasons for not performing CPR is informative" [p. 334]. They emphasized that there is potential to change CPR-related attitudes and beliefs and proposed different forms of educational intervention to achieve this. Axelsson Herlitz, \& Fridlund (2000) also argued that CPR trainings should include appropriate models to produce the feelings of personal responsibility and courage required to intervene and to prepare lay helpers emotionally for dealing with unexpected and unwanted situations.

\footnotetext{
* Corresponding author. Tel.: +31455762800.

E-mail addresses: birgit.schmitz@ou.nl (B. Schmitz), p.schuffelen@maastrichtuniversity.nl (P. Schuffelen), karel.kreijns@ou.nl (K. Kreijns), roland.klemke@ou.nl (R. Klemke), marcus.specht@ou.nl (M. Specht).
}

1 Tel.: +31455762800. 